\title{
Assess the Impact of Targeting Subsidies on the Development of Rural Settlements
}

\author{
Majid Saeidi Rad* \\ Department of Earth Sciences, shahid Beheshti University, Iran
}

Submission: August 02, 2019; Published: November 07, 2019

*Corresponding author: Majid Saeidi Rad, PhD in Human Geography, Department of Earth Sciences, shahid Beheshti University, Tehran, Iran

\begin{abstract}
Since the of targeting subsidies has been at the head of the government's economic development plans, this project the rural community in line with its policy has affected all classes of society. In this study, an attempt is made to assess the impact of implementation targeting subsidies law on the development of rural settlements in the central district of Borujerd county for "run-time assessment "is checked. The statistical population of this research is rural settlements in the central part of Borujerd County. The sample size was 286 people and the subjects were studied by simple random sampling. Finally, spss software was used for data analysis. Kind of research is applied and research method is descriptive and analytical research and data collection, library documentation and field that for the analysis of data from the questionnaires, the two methods of descriptive and inferential statistics (Kendall's tau-b, Spearman and multiple regression) using is. The results show that the correlation between the targeting subsidies and the Rural Development in this area is significant [1-4].
\end{abstract}

Keywords: Structural Adjustment Policies; Targeting Subsidies; Development; Rural Settlements

\section{Introduction}

With the evolution of economic theories, the role and position of the state has been transformed, so that the optimal allocation of resources, economic stability and distribution of income are among the main tasks of governments. In some cases, the optimal allocation of resources between sectors and economic activities is not naturally achieved and, with the imbalance in economics, Pareto efficiency access is not possible. As well, with the implementation of the historical evolution targeting subsidies law in 2010, surgery economic transition period of economic subsidies to be economically competitive and released after two decades of waiting, operational and research on the subject from the perspective of monitoring and impact assessment after the run, has entered a new realm [57]. Since the of targeting subsidies has been at the head of the government's economic development plans, this project the rural community in line with its policy has affected all classes of society. In this study an attempt is made to assess the impact of implementation targeted subsidies law to the development of rural settlements the central district of Borujerd county for "run-time assessment" is checked [8].

In rural settlements around Boroujerd city, the purpose of subsidies is the emergence of social and spatial effects [9]. In order to compare the theoretical and objective issues, the purposeful targeted of subsidies with the realities of rural society in the central part of the city, from the perspective of its impact on rural development indicators In this research, an attempt is made to evaluate the effects of law enforcement on subsidies on the four dimensions of economic, socio-cultural, environmental and physical infrastructure of rural settlements under study [10].

\section{The Study Area}

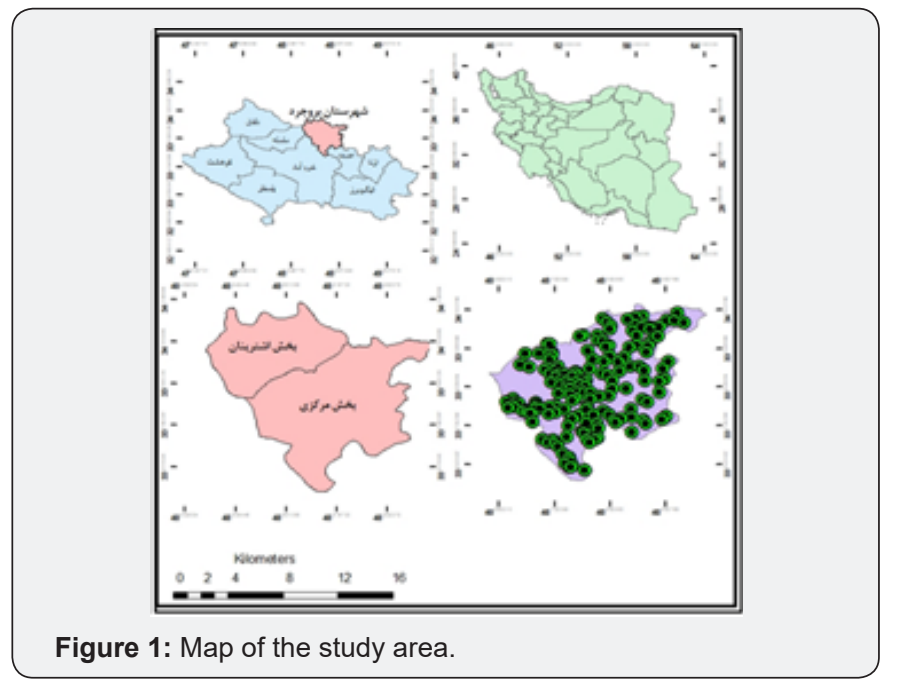


Boroujerd County is one of the 429 County of Iran and located on the geographical coordinates of $33^{\circ} 36^{\prime} 12^{\prime \prime} \mathrm{N} 48^{\circ} 35^{\prime} 26^{\prime \prime} \mathrm{E}$ (Figure 1).

\section{Methodology}

Kind of research is applied and research method is descriptive and analytical research and data collection, library documentation and field that for the analysis of data from the questionnaires, the two methods of descriptive and inferential statistics (Kendall's tau-b, Spearman and multiple regression) using is. Variables to measure the level of development of rural settlements of 56 items in the 4 criteria of environmental system, social system, economic system and physical system is measured. In relation to influence the process of targeted subsidies in the territorial space and rural settlements of 38 items within 7 standards of education and awareness, knowledge and skill, empowerment, service backup production and food security, access to financial resources, partnerships and policies is measured [11-13]. Thus, by analyzing the questionnaires of sampled households in rural areas of the central district of Boroujerd County, it was clarified that the targeting subsidies on the level of development and stability of rural settlements is effective $[14,15]$.

\section{Results and Discussion}

Distribution of cash Transfer in many countries as one of the most important factors affecting the spatial system of the settlement, in addition to the development and structure and performance of the regions and districts, Cause improves the level of development of the indicators of the environmental, socio-economic, physical and infrastructural systems in Rural settlements $[16,17]$. Thus, the neglected sections of the spatial and interactive components (Targeting Subsidies) with the level of development of rural settlements in the central part of Borujerd County, are potentials that can be effective in improving the development indicators of Rural settlements. The results show that the correlation between the targeting subsidies and the Rural Development in this area is significant [18-21].

\section{Conclusion}

Considering the positive role played by targeting subsidies and the development of rural communities and settlements, as well as the numerous emphasis of many scholars as well as the experiences of other countries in this regard, the need for the government to promote these indicators and enhance the empowerment of local residents through the provision of credit services and Improving the rural business environment in this regard will improve the status of development indicators of rural settlements in the central part of Borujerd county [22-24]. The findings of this study indicate that lack of proper mechanism for law enforcement of subsidies in the agricultural sector and rural community has led to the instability of rural settlements in the central part of Borujerd city [25]. Therefore, local stakeholders, as they should have not been able to make the necessary investments in the process of improving the process Production and employment caused by the law enforcement purpose of subsidies [26].

\section{References}

1. Attanasio O, Pellerano L, Reyes SP (2009) Building trust? Conditional cash transfer programmes and social capital. Fiscal Studies 30(2): 139177.

2. Bucher A (2010) Impacts of hiring subsidies targeted at the long-term unemployed on the low-skilled labor market: The French experience. Economic Modelling 27(2): 553-565.

3. Borujerd Special Governorate (2011) Deputy Minister of Development. Infrastructure Report of Rural Areas of Borujerd County.

4. Davies S, Davey J (2008) A regional multiplier approach to estimating the impact of cash transfers on the market: The case of cash transfers in rural Malawi. Development Policy Review 26(1): 91-111.

5. Farzin M, Hosseini S, Moohadnezhad A (2012) The Basics of Economic Transformation with Emphasis on the targeted Subsidies, Tehran, Deputy Economic Affairs Department of Economic Affairs and Finance.

6. Fatahi A (2006) Experience of State Capitalism in Iran, Tehran, Marzfakr.

7. Farahani H, Asdaghi Z, Tulabbi Nejad M (2013) The Analysis of the Impact of the Targeting Subsidy in Economic Empowerment of Rural Households, Case: Jaider District in Poldokhtar. Quarterly Journal of Space Economy and Rural Development 2 (5): 23-38.

8. Ghasemi M, Abdollahi S, Khakshur H (2014) Analysis of the effects of the first phase of the targeting subsidies plan on rural households (Case study; Binalood County). Journal of Research and Rural Planning 3(6): 124-137.

9. Hafeznia M (2009) Introduction to the Research Method in the Humanities, Tehran: Samt Publications.

10. Haushofer J, \& Shapiro J (2010) Household response to income changes: Evidence from an unconditional cash transfer program in Kenya. Massachusetts Institute of Technology.

11. Hosseini S, Maleki A (2005) Subsidy payment method and its selection criteria; Study of the experience of selected countries and Iran. Trading reviews 31: 16-25.

12. Jalalian H, Pasazazadeh A (2014) Economic and Social Impact of Paid Cash Transfer on Rural Communities (Case Study: Azadlo District in Garmi County). Journal of Planning Human Settlements 9(28): 103121.

13. Karimi F, Zahedi Keivan M (2010) Determining the Optimal Model for Allocation of Agricultural Subsidies to Consumers and Producers (Analytical Hierarchy Process). Journal of Agricultural Economics 2(8): 99-120.

14. Kothari CR (2009) Research methodology, method and techniques (Second Revised Edition), New Age International Publishers. New Delhi. pp. 1-401.

15. Kalantari Kh (2006) Data processing and analysis in socio-economic research using SPSS software, Tehran: Sharif Publishing, Second Edition.

16. Miller CM, Tsoka M, Reichert K (2011) The impact of the Social Cash Transfer Scheme on food security in Malawi. Food policy 36(2): 230238.

17. Molyneux M, Thomson M (2011) Cash transfers, gender equity and women's empowerment in Peru, Ecuador and Bolivia. Gender \& Development 19(2): 195-212. 
18. Ministry of Commerce (2008) Targeting subsidies; studying the concept and experience of countries, Tehran, Deputy Director of Planning and Economic Affairs, Office of Economic Studies.

19. Momeni F (2009) Economic Policies Social Justice and Agricultura Sector. Social Welfare 10(38): 329-366.

20. Nili M (2006) City Councils and Urban Economics. Industry and Development 2: 3-4.

21. Nourallahi E, Ghasemi M, Noghani M (2017) The Effectiveness of Targeting Subsidies on the Quality of Life of Villagers Case: Villages Ahmadabad District in Mashhad County. Quarterly Journal of Space Economy and Rural Development 6(3): 57-80.

22. OECD (2005) Subsidy Reform and Sustainable Development; Economic, Environmental and social aspects.
23. Rahimibrujerdi A (2007) Economic liberalization from theory to practice, Tehran, Samt Publications.

24. Semerci A (2013) The Effects of Agricultural Subsidies on Sunflower Cultivation and Farmers Income: Evidence from Turkey. Pak J Agri Sci 50(1): 139-145.

25. Todd JE, Winters PC, Hertz T (2010) Conditional cash transfers and agricultural production: lessons from the Oportunidades experience in Mexico. The Journal of Development Studies 46(1): 39-67.

26. Woods M (2011) Rural Geography (Processes, Reactions and Experience of Rural Rehabilitation), Translator Rezvani, Mohammad Reza and Farhadi, Samati, Tehran: Tehran University Press.

\section{Your next submission with Juniper Publishers will reach you the below assets}

- Quality Editorial service

- Swift Peer Review

- Reprints availability

- E-prints Service

- Manuscript Podcast for convenient understanding

- Global attainment for your research

- Manuscript accessibility in different formats

(Pdf, E-pub, Full Text, Audio)

- Unceasing customer service

Track the below URL for one-step submission https://juniperpublishers.com/online-submission.php 